\title{
Growth Performance, Gut Microbiota and Haemato-Biochemical Profile of Quails Fed Diet Supplemented with Graded Levels of $D$. glomerata Fruit Powder
}

\author{
Ebile Dayan Agwah, Kana Jean Raphaël*, Edie Nounamo Langston Wilfried, \\ Pimagha Moffo Herman Joël, Nguefack Djieufo Gildas, Ngouana Tadjong Ruben, \\ Mube Kuetchie Hervé, Fonteh Anyangwe Florence
}

Department of Zootechny, University of Dschang, Dschang, Cameroon

Email address:

kanajean@yahoo.fr (K. J. Raphaël)

${ }^{*}$ Corresponding author

\section{To cite this article:}

Ebile Dayan Agwah, Kana Jean Raphaël, Edie Nounamo Langston Wilfried, Pimagha Moffo Herman Joël, Nguefack Djieufo Gildas, Ngouana Tadjong Ruben, Mube Kuetchie Hervé, Fonteh Anyangwe Florence. Growth Performance, Gut Microbiota and HaematoBiochemical Profile of Quails Fed Diet Supplemented with Graded Levels of D. glomerata Fruit Powder. Animal and Veterinary Sciences. Vol. 6, No. 5, 2018, pp. 80-87. doi: 10.11648/j.avs.20180605.13

Received: October 19, 2018; Accepted: November 2, 2018; Published: November 28, 2018

\begin{abstract}
As a consequence of the antibiotics growth promoters restriction in livestock farming, there is a growing interest in plant feed additives. This study was designed to evaluate the effects of supplementing D. glomerata fruit powder on growth performance of Japanese quails. A total of 200 two weeks-old Japanese quail were randomly allocated to five experimental treatment groups. Experimental diets consisted of incorporating D. glomerata powder in the control ration (T0) at $2 \mathrm{~g}(\mathrm{~T} 1), 4 \mathrm{~g}$ (T2) and $6 \mathrm{~g} / \mathrm{kg}$ (T3) of feed. Quails fed with D. glomerata supplemented diets were compared to quails fed on diet without any supplement $(\mathrm{T} 0)$ and an antibiotic $(1 \mathrm{~g} / \mathrm{kg})$ medicated diet $(\mathrm{T} 0+)$. Throughout the production period feed intake was not significantly affected by the experimental rations. Weight gain was significantly higher $(p<0.05)$ with $4 \mathrm{~g} / \mathrm{kg}$ and $6 \mathrm{~g} / \mathrm{kg} D$. glomerata, while feed conversion ratio was significantly lower $(p<0.05)$ when compared to the control groups. Carcass yield of quails fed on antibiotic and $4 \mathrm{~g} / \mathrm{kg} D$. glomerata were statistically higher $(p<0.05)$ compared to the negative control diet. However, dietary treatments had no significant effect $(p>0.05)$ on the relative weight of organs when compared to the control diets. WBC, MCV, MCH, and MCHC were not significantly $(p>0.05)$ affected by this spice. RBC significantly increased $(p<0.05)$ with $6 \mathrm{~g} / \mathrm{kg} D$. glomerata compared to the negative control diet, while Hgb and PCV decreased $(p<0.05)$ compared to the positive control diet for the same treatment. Serum content in triglycerides was significantly higher $(p<0.05) \mathrm{with} 6 \mathrm{~g} / \mathrm{kg} D$. glomerata compared to all other treatments. ASAT, ALAT, creatinine, total protein, albumin, urea, total cholesterol, HDL, LDL were not significantly affected by the inclusion of $D$. glomerata in the ration. Irrespective of the level of incorporation of $D$. glomerata, lactic acid bacteria count significantly increased as compared to Escherichia coli, Samonella and Staphylococcus $s p p$. In conclusion, D. glomerata can be used up to $4 \mathrm{~g} / \mathrm{kg}$ as substitutes for infeed antibiotics for gut microbiota modulation and better weight gain without any adverse effects on the haemato-biochemical parameters of quail.
\end{abstract}

Keywords: Dichrostachys glomerata, Gut Microbiota, Haemato-Biochemical, Japanese Quails

\section{Introduction}

Antibiotics have been traditionally used for the feeding of monogastrics as growth promoter to improve the growth performance and the prevention of diseases $[1,2]$. However, the continuous consumption of antibiotics at subtherapeutical level increases the possibility of finding antibiotics residues on the animal products and the development of bacteria resistant to these substances [2]. Besides, antibiotics damage the ecological balance of the 
gastrointestinal biota, hence predisposing animals to diseases. Despite the current use of a variety of alternative growth and production enhancers, there is no single treatment or product that has been successful in replicating the relatively consistent and robust effects of antibiotic growth promoters.

Natural substances from plant origin are investigated as a possible solution that would address public health concerns without compromising the efficiency of poultry production [3]. Plant additives, are often referred to as phytobiotics, a term used to describe plant-derived natural bioactive compounds that affect animal growth and health; mostly applied to essential oils, botanicals and extracts derived from herbal plants $[4,5]$. Plant supplements are common dietary additives for humans, preferred because of their non-toxic chemical composition, relatively low cost and easy availability [6, 7]. However, for use in animal diets, knowledge with regards to their modes of action and aspects of their application is still very limited [5].

Dichrostachys glomerata has been shown to have antiviral, anti-infectious [8], anti-inflammatory, and analgesic effects [9]. This fruit also exhibit in vitro and in vivo antioxidant activity and can inhibit oxidation of low-density lipoproteins [10]. These authors also reported the ability of Dichrostachys glomerata to reduce fasting blood glucose and glycosylated hemoglobin levels. This spice acts indirectly on broiler growth performance and meat quality characteristics through their antimicrobial, antioxidant and regulator effects on animal's intestinal microflora [11-13]. Dichrostachys glomerata has inhibitory effects on the growth of Staphylococcus epidermidis, Streptococcus viridans and Escherichia coli [14]. We believe that the antimicrobial and antioxidant activity of this spice could help balance gut microflora, ensure good health and welfare, which can positively affect growth performances of grower quails. The main objective of this study is to evaluate the potential of natural substances from plants origin as feed additives, in order to mitigate the problems involved in antibiotic growth promoters in poultry production.

\section{Materials and Methods}

\subsection{Area of Study}

The study was carried out at the Teaching and Research Farm of the Faculty of Agronomy and Agricultural Sciences, University of Dschang, Cameroon. This farm is located at an altitude of $1420 \mathrm{~m}$ above sea level, between latitude $5^{\circ} 26^{\prime} \mathrm{N}$ and longitude $10^{\circ} 26^{\prime} \mathrm{E}$ with an equato-guinean climate, tempered by altitude.

\subsection{Feed Additives}

Dried sample of Dichrostachys glomerata fruit was bought at the local market in Dschang, ground into powder in a Harmed mill, sieved and incorporated in the experimental diets. The grounded spice sample was put in polyethylene plastic, sealed and stored at $4^{\circ} \mathrm{C}$ in a refrigerator until analysis. Antibiotic (Doxycyclin ${ }^{\circledR}$ ) used in the positive control diet was bought from a local veterinary pharmacy.

\subsection{Animal and Experimental Diets}

A total of 200 two weeks old Japanese quail chicks were randomly assigned to four experimental diets in a completely randomized design with 40 quails per treatment. Each group was sub divided into 4 replicates of 10 quails each $(5$ males and 5 females). Three experimental diets were formulated from a negative control diet (T0) (Table 1) by incorporating 1 $\mathrm{g}$ of antibiotic/kg of feed (T0+), $2 \mathrm{~g} / \mathrm{kg}$ (T1), $4 \mathrm{~g} / \mathrm{kg}$ (T2), and $6 \mathrm{~g} / \mathrm{kg}$ (T3) of Dichrostachys glomerata powder. Prophylactic measures against the most common infectious diseases were carried out. The quails were given treatment against coccidiosis $\left(\right.$ Vetacox $^{\circledR}$ ) and vitamins (AMINTOTAL ${ }^{\circledR}$ ) in water once a week. Chicks were weighed at the beginning of the experiment and on weekly basis thereafter, for a period of five weeks. Throughout the experiments, the quails received feed and water ad libitum every day. The quails were fed on a diet formulated to meet their requirements (Table 1).

Table 1. Composition of experimental diet.

\begin{tabular}{ll}
\hline Ingredients (\%) & Quantity(\%) \\
\hline Maize & 60 \\
Wheat brand & 4.5 \\
Soy bean meal & 22 \\
Fish meal & 4.5 \\
Bone meal & 2 \\
Oyster Shell & 2 \\
*Premix 5\% & 5 \\
Total & 100 \\
Calculated nutrients composition & \\
Metabolizable Energy (kcal/kg) & 2906.80 \\
Crude protein (\%) & 20.15 \\
Calcium \% & 2.03 \\
Phosphorus \% & 1.27 \\
Lysine (\%) & 0.44 \\
Methionine (\%) & 0.14 \\
Sodium (\%) & 0.22 \\
\hline
\end{tabular}

*Vitamin premix provided per kilogram of diet: vitamin A, $3000000 \mathrm{IU}$, vitamin D3: $600000 \mathrm{IU}$; vitamin E: $4000 \mathrm{mg}$; vitamin $\mathrm{K}$ : $500 \mathrm{mg}$; vitamin B1: $200 \mathrm{mg}$; vitamin B2, 1000mg; vitamin B6: $400 \mathrm{mg}$; vitamin B12: $4 \mathrm{mg}$; Mn, 80 mg; Fe: 8000 mg; Zn: 10000 mg; Cu,: 2000mg; Methionine: 200000 $\mathrm{mg}$; Lysine: $78000 \mathrm{mg}$; Se: $20 \mathrm{mg}$

\subsection{Carcass yield, Haematological and Serum Biochemical Parameters}

At the end of the feeding trial, one male and one female from each replicate within the treatment ( 8 quails per treatment) were selected for carcass evaluation. They were fasted for 12 hours after which they were weighed and slaughter. Evisceration was done by hand plucking of feathers in warm water, removal of shank and viscera were recorded individually and presented as a percentage of live body weight. From each slaughtered quail, blood was collected in 02 test tubes, one of which contained an anticoagulant. Blood with anticoagulant was used for hematological analysis using full automatic blood cell counter (Model PCE- 21ON Hong Kong, China). Hematological parameters included White blood cell (WBC), Red blood cell (RBC), Haemoglobin (Hgb), Mean cell 
volume (MCV), Mean cell haemoglobin concentration (MCHC), Mean cell haemoglobin $(\mathrm{MCH})$ and Pack cell volume (PCV). Meanwhile, after centrifugation of blood free from anticoagulant, serum was collected and preserved at $20^{\circ} \mathrm{C}$ for the evaluation of biochemical parameters (total protein, albumin, globulin, aspartate aminotransferase (ASAT), alanine aminotransferase (ALAT), total cholesterol, high density lipoproteins (HDL), low density lipoproteins (LDL), triglyceride, urea and creatinin) using the colorimetric method as prescribed by the commercial kits (Dialab ${ }^{\circledR}$ kits).

\subsection{Microbial Count}

The sterile spatula was use to collect freshly quail droppings into sample bottles. The identification and quantification of bacteria from each treatment were counted on appropriate specific culture medium (MRS AGAR for lactic bacteria, Mac Conkey AGAR for E. coli, SS AGAR for Salmonella and MST AGAR for Staphylococcus) respectively after incubation for 24 hours.

\subsection{Statistical Analysis}

Data recorded were submitted to one-way analysis of variance test by General Linear Model procedure of Statistical Package for Social Science (SPSS 20.0) software. The differences were tested using a Duncan's multiple range's test and probability values less than 0.05 were considered as significant [15].

\section{Results}

Table 2 summarized the overall growth performance of Japanese quails fed graded levels of $D$. glomerata fruit powder. The results of the present study indicated no significant effects $(p>0.05)$ among the treatment groups for feed intake and final body weight. Weight gain (WG) significantly increased $(p<0.05)$ with 4 and $6 \mathrm{~g} \quad D$. glomerata $\mathrm{kg}$ of feed, while feed conversion ratio (FCR) significantly decreased $(p<0.05)$ for the same treatments as compared to the negative and positive control diets.

Table 2. Growth performance of Japanese quails fed graded levels of D. glometrata.

\begin{tabular}{|c|c|c|c|c|c|c|c|}
\hline \multirow{2}{*}{ Growth parameters } & \multicolumn{5}{|c|}{ Treatments } & \multirow{2}{*}{ SEM } & \multirow{2}{*}{ p-value } \\
\hline & T0 & T0+ & T1(2g) & T2(4g) & T3(6g) & & \\
\hline Feed intake $(\mathrm{g})$ & 146.8 & 137.89 & 133.3 & 142.93 & 137.84 & 8.27 & 0.58 \\
\hline Final body weight (g) & 259.03 & 269.93 & 265.13 & 283.25 & 279.8 & 11.65 & 0.25 \\
\hline Weight gain $(\mathrm{g})$ & $26.48^{\mathrm{b}}$ & $24.75^{\mathrm{b}}$ & $24.24^{\mathrm{b}}$ & $31.74^{\mathrm{a}}$ & $31.70^{\mathrm{a}}$ & 2.91 & 0.04 \\
\hline FCR & $5.64^{\mathrm{a}}$ & $5.59^{\mathrm{a}}$ & $5.56^{\mathrm{a}}$ & $4.53^{\mathrm{b}}$ & $4.41^{\mathrm{b}}$ & 0.46 & 0.03 \\
\hline
\end{tabular}

a.b: Means on the same row with different superscripts are significantly different $(P<0.05)$. SEM= standard error on mean; $\mathrm{p}=$ probability. T0 $=$ negative control diet; $\mathrm{T} 0+=\mathrm{T} 0+0.1 \%$ of Doxycycline; $\mathrm{T} 1=\mathrm{T} 0+2 \mathrm{~g}$ D. glomerata powder per kilogram of feed; $\mathrm{T} 2=\mathrm{T} 0+4 \mathrm{~g} D$. glomerata powder per kilogram of feed. $\mathrm{T} 3=$ $\mathrm{T} 0+6 \mathrm{~g}$ D. glomerata powder per kilogram of feed.

Carcass characteristics and relative weight of organs expressed in proportion of body weight of quails fed graded levels of $D$. glomerata powder are presented in table 3 . The average value of carcass yield of quails fed on diet supplemented with $4 \mathrm{~g} / \mathrm{kg}$ was significantly higher $(p<0.05)$ compared to quails fed on negative control diet. There was no marked ( $p>0.05)$ effects on the relative weight of the liver, pancreas, heart, legs and abdominal fat, except for the relative weight of the head that decreased significantly $(p<0.05)$ in quails fed $6 \mathrm{~g} / \mathrm{kg}$ compared to birds fed $2 \mathrm{~g} / \mathrm{kg}$ and $4 \mathrm{~g} / \mathrm{kg}$ D. glomerata.

Table 3. Effects of graded levels of D. glomerata on carcass yield and relative organs weight of Japanese quails.

\begin{tabular}{|c|c|c|c|c|c|c|c|}
\hline \multirow{2}{*}{ Carcass traits } & \multicolumn{5}{|c|}{ Treaments } & \multirow{2}{*}{ SEM } & \multirow{2}{*}{$p$-value } \\
\hline & T0 & T0+ & T1 (2g) & $\mathrm{T} 2(4 \mathrm{~g})$ & T3 (6g) & & \\
\hline Live weight (g) & 241.5 & 219.88 & 233.13 & 219.5 & 223.87 & 13.6 & 0.43 \\
\hline Carcass weight (g) & 163.5 & 165.87 & 170 & 169 & 160.75 & 8.87 & 0.83 \\
\hline \multicolumn{8}{|c|}{ Relative weight of organs (\% BW) } \\
\hline Liver & 2.36 & 1.82 & 1.79 & 1.87 & 2.49 & 0.36 & 0.18 \\
\hline Pancrease & 0.22 & 0.2 & 0.21 & 0.2 & 0.24 & 0.02 & 0.55 \\
\hline Head & $4.87^{\mathrm{ab}}$ & $4.84^{\mathrm{ab}}$ & $4.97^{\mathrm{a}}$ & $4.98^{\mathrm{a}}$ & $4.26^{\mathrm{b}}$ & 0.32 & 0.03 \\
\hline Legs & 1.79 & 1.95 & 1.95 & 1.8 & 1.72 & 0.31 & 0.33 \\
\hline Abdominal fat & 1.11 & 1.24 & 1.1 & 1.28 & 1.04 & 0.25 & 0.85 \\
\hline
\end{tabular}

a.b: Means on the same row with different superscripts are significantly different $(P<0.05)$. SEM= standard error on mean; $p=$ probability. T0 $=$ negative control diet; $\mathrm{T} 0+=\mathrm{T}_{0}+0.1 \%$ of Doxycycline; $\mathrm{T} 1=\mathrm{T} 0+2 \mathrm{~g}$ D. glomerata powder per kilogram of feed; $\mathrm{T} 2=\mathrm{T} 0+4 \mathrm{~g} D$. glomerata powder per kilogram of feed. $\mathrm{T} 3=$ $\mathrm{T} 0+6 \mathrm{~g}$ D. glomerata powder per kilogram of feed

Table 4, summarizes data on the effect of graded level of D. glomerata fruit powder on digestive organs of Japanese quails. Intestinal weight and intestinal density were significantly $(p<0.05)$ higher with $6 \mathrm{~g}$ of $D$. glomerata in the ration compared to birds fed on the positive control ration and $4 \mathrm{~g}$ of this phytobiotic, while no marked $(p>0.05)$ effect was recorded for the gizzard and intestinal length irrespective of the treatment. 
Table 4. Effect of graded levels of D. glomerata on digestive organs of Japanese quails.

\begin{tabular}{|c|c|c|c|c|c|c|c|}
\hline \multirow{2}{*}{ Digestive organs traits } & \multicolumn{5}{|c|}{ Treatments } & \multirow{2}{*}{ SEM } & \multirow{2}{*}{ p-value } \\
\hline & T0 & T0+ & T1 (2g) & T2 (4g) & T3 (6g) & & \\
\hline Gizzard (g) & 1.45 & 1.41 & 1.24 & 1.15 & 1.47 & 0.39 & 0.56 \\
\hline Intestinal weight (g) & $7.05^{\mathrm{ab}}$ & $6.21^{\mathrm{b}}$ & $7.14^{\mathrm{ab}}$ & $6.20^{\mathrm{b}}$ & $8.85^{\mathrm{a}}$ & 0.92 & 0.05 \\
\hline Intestinal lenght (cm) & 71.25 & 67.23 & 69.34 & 67.39 & 7.525 & 3.5 & 0.48 \\
\hline Intestinal density $(\mathrm{g} / \mathrm{cm})$ & $0.09^{\mathrm{b}}$ & $0.09^{\mathrm{b}}$ & $0.1^{\mathrm{ab}}$ & $0.09^{\mathrm{b}}$ & $0.12^{\mathrm{a}}$ & 0.01 & 0.04 \\
\hline
\end{tabular}

a,b , Means on the same row with different superscripts are significantly different $(P<0.05)$. SEM= standard error on mean; $p=$ probability. T0 $=$ negative control diet; $\mathrm{T} 0+=\mathrm{T} 0+0.1 \%$ of Doxycycline; $\mathrm{T} 1=\mathrm{T} 0+2 \mathrm{~g}$ D. glomerata powder per kilogram of feed; $\mathrm{T} 2=\mathrm{T} 0+4 \mathrm{~g} D$. glomerata powder per kilogram of feed. $\mathrm{T} 3=\mathrm{T} 0+6 \mathrm{~g} D$. glomerata powder per kilogram of feed.

The results on the haematological parameters of quails fed on graded level of D. glomerata are presented in Table 5. There were no significant $(p>0.05)$ differences in the values recorded on Mean corpuscular haemoglobin $(\mathrm{MCH})$, Mean corpuscular haemoglobin concentration (MCHC) Mean corpuscular volume (MCV) and white blood cell (WBC) between the birds on the reference diet and those on the test diets. Birds fed with $6 \mathrm{~g} / \mathrm{kg} D$. glomerata recorded a significantly $(p<0.05)$ higher $\mathrm{RBC}$ value compared to birds fed on negative control diet. Haemoglobin and PCV of birds fed with $6 \mathrm{~g} / \mathrm{kg} D$. glomerata were significantly lower $(p<0.05)$ compared to quails fed on positive control diet.

Table 5. Haematological parameters of Japanese quails fed on graded levels D. glomerata.

\begin{tabular}{|c|c|c|c|c|c|c|c|}
\hline \multirow{2}{*}{ Blood parameters } & \multicolumn{5}{|c|}{ Treatments } & \multirow{2}{*}{ SEM } & \multirow{2}{*}{$P$-value } \\
\hline & T0 & T0+ & T1 (2g) & T2 (4g) & T3 (6g) & & \\
\hline WBC $\left(10^{3} / \mathrm{ul}\right)$ & 79,4 & 77.17 & 85.13 & 88.37 & 81.22 & 6.84 & 0.5 \\
\hline $\mathrm{RBC}\left(10^{6} / \mathrm{ul}\right)$ & $3.29^{\mathrm{b}}$ & $3.84^{\mathrm{a}}$ & $3.37^{\mathrm{ab}}$ & $3.69^{\mathrm{ab}}$ & $3.9^{\mathrm{a}}$ & 0.25 & 0.05 \\
\hline $\operatorname{Hgb}(\mathrm{g} / \mathrm{dl})$ & $13.97^{\mathrm{ab}}$ & $16.38^{\mathrm{a}}$ & $14.42^{\mathrm{ab}}$ & $15.52^{\mathrm{ab}}$ & $12.95^{\mathrm{b}}$ & 1.32 & 0.02 \\
\hline $\operatorname{MCV}(f l)$ & 148.6 & 149.45 & 152.61 & 150.31 & 146.55 & 5.44 & 0.85 \\
\hline MCH (pg) & 42.31 & 42.47 & 42.5 & 41.98 & 40.41 & 1.35 & 0.52 \\
\hline $\mathrm{MCHC}(\mathrm{g} / \mathrm{dl})$ & 28.4 & 28.45 & 27.88 & 27.88 & 27.58 & 0.98 & 0.88 \\
\hline
\end{tabular}

a,b: Means on the same row with different superscripts are significantly different $(\mathrm{P}<0.05)$. SEM= standard error on mean; $\mathrm{p}=$ probability. T0 $=$ negative control diet; $\mathrm{T} 0+=\mathrm{T} 0+0.1 \%$ of Doxycycline; $\mathrm{T} 1=\mathrm{T} 0+2 \mathrm{~g}$ D. glomerata powder per kilogram of feed; $\mathrm{T} 2=\mathrm{T} 0+4 \mathrm{~g} D$. glomerata powder per kilogram of feed. $\mathrm{T} 3=\mathrm{T} 0+6 \mathrm{~g}$ D. glomerata powder per kilogram of feed.

Table 6 indicates that, feeding quails with $4 \mathrm{~g} / \mathrm{kg} D$. glomerata significantly $(P<0.05)$ decrease total protein serum content compared to quails fed on positive control diet. Birds fed with $6 \mathrm{~g} / \mathrm{kg}$ D. glomerata recorded the lowest $(p<0.05)$
LDL-cholesterol content compared to birds fed with $4 \mathrm{~g} / \mathrm{kg}$

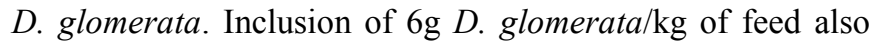
induced a marked $(p<0.05)$ increase in triglycerides content compared to all other treatments.

Table 6. Biochemical parameters of Japanese quails fed on graded level of D. glomereta.

\begin{tabular}{|c|c|c|c|c|c|c|c|}
\hline \multirow{2}{*}{ Biochemical parameters } & \multicolumn{5}{|c|}{ Treaments } & \multirow{2}{*}{ SEM } & \multirow{2}{*}{ p-value } \\
\hline & T0 & T0+ & T1 (2g) & T2 (4g) & T3 (6g) & & \\
\hline ASAT (U/I) & 272.52 & 264.70 & 246.30 & 274.49 & 241.62 & 58.11 & 0.97 \\
\hline ALAT (U/I) & 17.19 & 17.15 & 17.43 & 17.79 & 14.79 & 2.72 & 0.82 \\
\hline Creatinine (mg/dl) & 0.35 & 0.31 & 0.33 & 0.44 & 0.36 & 0.60 & 0.4 \\
\hline Total protein $(\mathrm{mg} / \mathrm{dl})$ & $1.73^{\mathrm{ab}}$ & $2.05^{\mathrm{a}}$ & $1.64^{\mathrm{ab}}$ & $1.55^{\mathrm{b}}$ & $1.72^{\mathrm{ab}}$ & 0.220 & 0.03 \\
\hline Abulmin $(\mathrm{mg} / \mathrm{dl})$ & 1.13 & 0.89 & 0.84 & 0.93 & 0.98 & 0.50 & 0.38 \\
\hline Urea $(\mathrm{mg} / \mathrm{dl})$ & 9.32 & 8.68 & 7.43 & 8.68 & 6.98 & 7.71 & 0.32 \\
\hline $\mathrm{HDL}(\mathrm{mg} / \mathrm{dl})$ & 90.02 & 76.20 & 94.50 & 103.42 & 61.10 & 24.74 & 0.48 \\
\hline $\operatorname{LDL}(\mathrm{mg} / \mathrm{dl})$ & $105.74^{\mathrm{ab}}$ & $107.62^{\mathrm{ab}}$ & $80.63^{\mathrm{ab}}$ & $118.1^{\mathrm{a}}$ & $39.01^{\mathrm{b}}$ & 31.83 & 0.02 \\
\hline Triglycerides (mg/dl) & $183.33^{\mathrm{b}}$ & $327^{\mathrm{ab}}$ & $206.93^{\mathrm{b}}$ & $197.03^{\mathrm{b}}$ & $529.82^{\mathrm{a}}$ & 100.84 & 0.01 \\
\hline
\end{tabular}

a,b: Means on the same row with different superscripts are significantly different $(P<0.05)$. SEM= standard error on mean; $p=$ probability. T0 $=$ negative control diet; $\mathrm{T} 0+=\mathrm{T} 0+0.1 \%$ of Doxycycline; $\mathrm{T} 1=\mathrm{T} 0+2 \mathrm{~g}$ D. glomerata powder per kilogram of feed; $\mathrm{T} 2=\mathrm{T} 0+4 \mathrm{~g} D$. glomerata powder per kilogram of feed. $\mathrm{T} 3=\mathrm{T} 0+6 \mathrm{~g}$ D. glomerata powder per kilogram of feed.

The results on the intestinal microbial count are summarized in table 7. No marked effect of the tested spice was recorded on lactic bacteria count when compared to the negative control diet. Samonella counts significantly $(p<0.05)$ decreased with antibiotic medication and $D$. glomerata inclusion in feed, while reverse trend was observed with Staphylococcus spp. Quails fed with 2 and $6 \mathrm{~g}$
D. glomerata $/ \mathrm{kg}$ of feed and the positive control diet significantly $(p<0.05)$ decreased $E$. coli counts. Regarding the bacterial species, the inclusion of $6 \mathrm{~g} D$. glomerata powder and antibiotic inclusion in quail's feed markedly $(p<0.05)$ increased the number of lactic bacteria colonies as compared to salmonella, E. coli and staphylococcus. 
Table 7. Faecal microbial counts of Japanese quails fed on graded levels D. glomerata

\begin{tabular}{|c|c|c|c|c|c|c|c|}
\hline Bacteria load $\log _{10}(\mathrm{cfu})$ & T0 & T0+ & T1 (2g) & T2 (4g) & T3 (6g) & SEM & P-value \\
\hline Lactobacillus & $8.59^{\mathrm{b}}$ & $8.93^{\mathrm{a}}$ & $8.77^{\mathrm{ab}}$ & $8.75^{\mathrm{ab}}$ & $8.77^{\mathrm{ab}}$ & 0.14 & 0.027 \\
\hline E. coli & $8.75^{\mathrm{a}}$ & $8.32^{\mathrm{b}}$ & $8.42^{\mathrm{b}}$ & $8.51^{\mathrm{ab}}$ & $8.2^{\mathrm{b}}$ & 0.15 & 0.021 \\
\hline Salmonella & $8.56^{\mathrm{a}}$ & $7.82^{\mathrm{c}}$ & $8.16^{\mathrm{b}}$ & $8.16^{\mathrm{b}}$ & $8.05^{\mathrm{bc}}$ & 0.13 & 0.002 \\
\hline Staphylococcus spp & $0^{\mathrm{cB}}$ & $6.12^{\mathrm{b}}$ & $6.27^{\mathrm{b}}$ & $6.44^{\mathrm{ab}}$ & $6.61^{\mathrm{a}}$ & 0.15 & 0.000 \\
\hline
\end{tabular}

a.b, c: Means on the same row with different superscripts are significantly different $(P<0.05)$.

$\mathrm{T} 0=$ negative control diet; $\mathrm{T} 0+=\mathrm{T} 0+0.1 \%$ of Doxycycline; $\mathrm{T} 1=\mathrm{T} 0+2 \mathrm{~g}$ D. glomerata powder per kilogram of feed; $\mathrm{T} 2=\mathrm{T} 0+4 \mathrm{~g} D . \mathrm{glomerata}$ powder per kilogram of feed. $\mathrm{T} 3=\mathrm{T} 0+6 \mathrm{~g}$ D. glomerata powder per kilogram of feed. SEM= standard error on mean; $p=$ probability.

\section{Discussion}

The incorporation of graded level of D. glomerata powder in quail's feed did not enhance feed intake (FI). It induced a non-significant decrease of about $9.19,2.64$ and $6.10 \%$ respectively with 2,4 and $6 \mathrm{~g}$ of $D$. glomerata as compared to the negative control diet. The decrease trend in FI observed in this study could be attributed to the presence of the bitter triterpenoids in D. glomerata fruits which may have reduced the palatability of feed. According to Fairchid et al. [16], birds have taste sensors for salt and bitterness, and it may therefore, be natural for the birds to consume less feed if it has a bitter taste. This result agrees with the findings of Kana et al. [13] who reported no significant effect on FI with the incorporation of $D$. glomerata in broilers feed. These authors explained the results by the high concentration of antinutritional, or strong odour of this spice that may have caused the feed to be unpalatable. This is also in agreement with the studies of Kalio et al. [17] that attributed a depression in FI by broilers to the non-palatability and probable presence of toxic or anti-nutritional factors inherent in the spices.

Weight gain (WG) of birds fed on 4 and $6 \mathrm{~g} D$. glomerata $/ \mathrm{kg}$ of feed significantly $(p<0.05)$ increased as compared to the negative and positive control diets. Final body weight (FBW) increased for about $2.35,9.35$ and $8.02 \%$ respectively with 2,4 and $6 \mathrm{~g} / \mathrm{kg}$ D. glomerata compared to the negative control ration. The reason for the improvement in weight gain with this spice could be attributed to their antimicrobial properties and impact on gut function as revealed by the previous findings $[12,18]$. The difference here could also be due to the genetic difference in the birds used [19]. This spice also contains phenolic and flavonoïds compounds which act by forming complexes with many proteins, causing the destruction of bacterial membranes, making unavailable certain substrates for the bacteria and inactivate bacterial enzymes [20]. Thus the reduction of the intestinal microbial count could lead to a greater availability of some nutriments for the host and consequently improve weight gain. This is in agreement with the report of Mcmullin [21] who observed that the growth promoting effect of most herbs and extracts of spices act by killing parasites that hinder digestibility and growth performance of birds. Several studies reported that phytobiotics improved intestinal health, animals are less exposed to microbial toxins and other undesired microbial metabolites $[22,23]$. This result is similar to the findings of Kana et al. [13] who reported that D. glomerata powder markedly improved the growth performances of chickens. The high weight gain recorded with $D$. glomerata powder compared to antibiotic could be explained by the absence of tannins in this spice. The favorable attributes of spices can be masked by tannins which affect the use of the nutrients and depress growth [24].

The inclusion of $D$. glomerata powder in quail feed at 4 and $6 \mathrm{~g} / \mathrm{kg}$ significantly $(\mathrm{p}<0.05)$ decreased gain/feed ratio compared to the control diets. This decreased in feed conversion ratio could be due to the efficient nutrient utilization by the birds on the test diets due to the depression of microbial toxins and other undesired microbial metabolites by the compounds present in this spice. This result is in close agreement with the findings of Kana et al. [13] who recorded a decrease in FCR with the inclusion of $0.2 \%$ and $0.4 \%$ of $D$. glomerata in broiler feed. The present result is in agreement with those of other authors, who reported that most herbs and extracts of spices work as growth promoters by killing parasites that hinder digestibility and growth performances of birds $[16,20-23]$. The decrease in feed conversion ratio in this study suggested that the digestibility of feed and the absorption of nutrients are better in quails fed $D$. glomerata powder fruit at $4 \mathrm{~g} / \mathrm{kg}$ and $6 \mathrm{~g} / \mathrm{kg}$.

Dressing percentage is a better index of total edible meat after the visceral organs; blood and feathers have been removed [25]. Based on the present study, quails fed on the experimental diets supplemented with $4 \mathrm{~g}$ D. glomerata $/ \mathrm{kg}$ of feed had significantly $(p<0.05)$ higher carcass yield compared to the negative control group, while the relative weight of organs was similar when compared to birds fed on the control diets. The improvement in carcass yield may be resulted in an increase in digestibility of nutrients which is optimal for better feed utilization with the addition of $D$. glomerata powder in feed. The present results contradiction the findings of Barad et al. [26] which revealed that $2 \%$ spices of coriander seed, turmeric powder and $0.5 \%$ black pepper had no significant effect on carcass yield and relative weight of organs in broiler chickens. Likewise, Kana et al. [27] reported no marked improvement on carcass yield when 2 and $3 \mathrm{~g}$ of Afrostyrax lepidophyllus were respectively added in broiler's feed. The present result is in agreement with the findings of Simsek et al. [28] who reported that, the addition of anise oil and essential oil mix (Herbomix) to diets had 
positive effects on carcass yield in broilers.

The intestinal density was significantly $(p<0.05)$ higher in quails fed with $6 \mathrm{~g} D$. glomerata $/ \mathrm{kg}$ of feed compared to quails fed on control rations and $4 \mathrm{~g} D$. glomerata $/ \mathrm{kg}$. This could be due to additional bulk and greater volume of digester staying in the gastrointestinal tract during enzymatic digestion. Bawa et al. [29] reported a significantly $(p<0.05)$ higher intestinal weight after feeding rabbits with raw neem seed meal for 63 days. Uchegbu et al. [30] also reported an increased in the intestine weight of broilers fed on Napoleona imperialis seed meal. The present result contradicts the findings of Abdel-Fatter et al. [31] and Kana et al. [32] who respectively reported that the inclusion of organic acids and the charcoal from Canarium schweinfurthii seeds in broilers diet tend to decrease the intestine density.

The Red blood cells count of grower Japanese quails supplemented with $6 \mathrm{~g} D$. glomerata $/ \mathrm{kg}$ was significantly $(P<0.05)$ higher compared to birds fed on negative control diet, while the hemoglobin ( $\mathrm{Hgb})$ and packed cell volume were lower compared to the positive control diet. This is an indication that Dichrostachys glomerata fruit may improve the oxygen carrying capacity of the birds and did not in any way render the birds anaemic. This finding differed from what was reported by Toghyani et al. [33] that supplementing broiler chickens with thyme powder did not have any marked effect on white and red blood cells counts, hemoglobin content and hematocrit percentage.

Serum contents in ALAT (alanine amino-transferase) and ASAT (aspartate amino-transferase), are used to evaluate liver function, the increased in their activities are related to degenerations of hepatocytes or liver damage irrespective of its origin $[34,35]$. This study revealed that feeding quails with $D$. glomerata powder at different concentrations had no significant $(p<0.05)$ effect on serum content in ASAT and ALAT. However, the inclusion of $6 \mathrm{~g} \mathrm{D.} \mathrm{glomerata} \mathrm{in} \mathrm{a} \mathrm{kg}$ of feed decreased serum content in ASAT and ALAT by 12.79 and $16.23 \%$ respectively compared to the negative control ration. This result is in accordance with the findings of Kana et al. [13] which revealed that, the incorporation of 0.2 and $0.4 \%$ of $D$. glomerata in broilers diet did not significantly affect the serum content in ASAT and ALAT. This observation contradicted the results of Rehman et al. [36] which revealed that feeding broiler with a mixture of aqueous extracts of medicinal plants induced a reduction in ALAT and ASAT. This contradiction can be due to the various active compounds in the mixture of the extracts used by these authors which could have affected liver function.

The serum content in urea and total proteins were not affected $(P>0.05)$ by the tested spice irrespective of the dose administered compared to the negative control. This suggests that $D$. glomerata fruit powder does not have harmful effects on kidney function (serum rate of urea) and the immune system (serum protein rate). This result contradicts the findings of Ngouana et al. [37] which revealed that, the incorporation of essential oils encapsulated in chitosan and charcoal in broilers feed increased the serum content in total protein and serum urea levels.
Plant extracts stimulate volatile fatty acids production and a reduction in digester $\mathrm{pH}$ of diets. Condensed tannins, on the contrary have a tendency to decrease the total caecal volatile fatty acid concentrations, possibly suppressing either activity or the numbers of gut micro-flora [7]. This study revealed that feeding quails with $6 \mathrm{~g} \mathrm{D}$. glomerata $/ \mathrm{kg}$ of feed markedly increased serum content in triglycerides. This could be explained by the ability of this spice to increase the secretion of bile salts which would have led to a better digestion of dietary lipids. Similarly, Bolukbasi et al. [38] reported an increase in triglyceride level in broilers fed with essential oil of thyme.

Regardless of the bacteria species, the number of bacteria count significantly $(P<0.05)$ increased in the test treatments compared to the control rations. However, the number of lactic bacteria count (beneficial bacteria) was higher than $E$. coli, salmonella and staphylococci (pathogenic bacteria). Suppression of harmful microorganisms resulted in the better growth and metabolism of beneficial microbes, which might have improved nutrient retention and weight gain in the present study. Antimicrobial activity of natural extracts and compressed oils are closely linked with their polyphenolic content [39]. Therefore, plant extracts rich in phenolic and other bioactive compounds may serve as potential natural antimicrobial agents $[40,41]$. These bioactive components i.e., tannins, saponins, flavonoids, phytosterols suppress potentially pathogenic bacteria in the intestine $[14,22,42]$.

\section{Conclusion}

Dichrostachys glomerata powder can be included up to $4 \mathrm{~g} / \mathrm{kg}$ diet as substitute for infeed antibiotics, for gut microbiota modulation and better growth performance of quails without any adverse effects on the haematobiochemical parameters, suggesting that this spice does not have harmful effects on liver and kidney function, and the immune system of the birds.

\section{References}

[1] Murry, A. C., Hinton, A. \& Buhr, R. J. 2006. Effect of botanical probiotic containing lactobacilli on growth performance and populations of bacteria in the ceca, cloacae, and carcass rinse of broiler chickens. Intern. J. Poult. Sci. 5: 344.

[2] Yanelys García Curbelo1, Mercedes. G. López2, R. Bocourt1, Zoraya Rodríguez1 and Lourdes Savón1., 2012. Prebiotics in the feeding of monogastric animals. Cuban Journal of Agricultural Science, Volume 46, Number 3, 2012.

[3] Suganya T., Seenthilkumar S., Deepa K., Muralidharan J., Gomathi G. and Gobiraju S. (2016). Herbal feed additives in poultry. International Journal of Science, Environment and Technology, 5(3): 1137-1145.

[4] Kim, S. W., Fan, M. Z. and Applegate, T. J. (2008). Non ruminant Nutrition symposium on natural phytobiotics for health of young animals and poultry: Mechanisms and application. Journal of Animal Science, 86 (E. Supplement): E138 - E139. 
[5] Windisch, W., Schedle, K., Plitzner, C. and Kroismayr A. (2008). Journal of Animal Science, 86 (E. Supplement): E140-E148.

[6] Ali M. N., Hassan M. S. and Abdel-Ghany F. A., 2007. Effect of strain, type of natural antioxidant and sulphate on productive, physiological and hatching performance of native laying hens. International Journal of Poultry Science, 6: 539554 .

[7] Cross, D. E., Mcdevitt, R. M. and Acamovic, T. (2011). Herbs, thyme essential oil and condensed tannin extracts as dietary supplements for broilers, and their effects on performance, digestibility, volatile fatty acids and organoleptic properties. British Poultry Science, 52 (2): 227 - 237.

[8] Fankam AG, Kuete V, Voukeng IK, Kuiate JR, Pages JM., 2011. Antibacterial activities of selected Cameroonian spices and their synergistic effects with antibiotics against multidrug-resistant phenotypes. BMC Complementary and Alternative Medicine 2011; 11: 104. doi: 10.1186 /14726882-11- 104 .

[9] Atsang AKG, Dzeufiet DPD, Foyet HS, Nana P, Sokeng DS, Dimo T, Kamtchouing P., 2012 Analgesic and AntiInflammatory Activities of Dichrostachys glomerata (Forssk.) Hutch. Fruits Methanolic Extract in Rats. J Phys Pharm Adv 2012; 2(8): 269-276.

[10] Kuate D, Etoundi BC, Ngondi JL, Oben JE., 2010 Effects of Dichrostachys glomerata spice on cardiovascular diseases risk factors in normoglycemic and type 2 diabetic obese volunteers. Food Res Int 2011; 44: 1197-02.

[11] Simitzis, P. E., Deligeorgis, S. G., Bizelis, J. A., Dardamani, A., Theodosiou, I., Fegeros K., 2008. Effect of dietary oreganooil supplementation on lamb meat characteristics. Meat Science 79: 217-223.

[12] Alloui N., S. Ben Aksa and M. N. Alloui. 2011. Utilization of fenugreek (Trigonella foenum-graecum) as growth promoter for broiler chickens. J. World Poult. Res. 2(2): 25-27.

[13] Kana J. R., Mube K. H., NgouanaTadjong R., Tsafong F., Komguep R., Yangoue A. and Teguia A. (2017a). Effect of Dietary Mimosa Small Bell (Dichostachysglomerata) Fruit Supplement as Alternative to Antibiotic Growth Promoter for Broiler Chicken. Journal World's Poultry Research, 7(1): 2734.

[14] Okerulu IO and Chinwe JA (2001). The phytochemical analysis and antimicrobial screening of extracts of Tetracarpidium conophorum. Journal of Chemical Society of Nigeria, 20 (1): 53-55.

[15] Steel R. G. D and Torrie J. H. (1980). Principles and Procedures Statistic. A biometrical approach. 2nd edition MC Grow hill books. Co. inc/New York U.S.A.

[16] Fairchid, B. D., Batal, A. B., Ritz, C. W. and Vendrell, P. F. (2005). Drinking Water iron concentration impact on broiler performance. Poultry Sci: 84, 103-194

[17] Kalio G. A., Wariboko O. N. and Okafor B. B., 2016 Growth Performance and Haematological Profile of Growing Japanese Quails Fed Graded Levels of AzadirachtaIndica Leaf Meal. $J$. Anim. Sci. Adv., 2016, 6(2): 1586-1594.

[18] Jane TN., Matthias O. A and Ikechukwu F. U., 2014. Antioxidant and hepato protective activity of fruit extracts of Tetrapleura tetraptera (Schum and Thonn) Taubert. Jordan
Journal of Biological Sciences, 7(4): 251-255.

[19] National Research Council, NRC (1994). Nutrient Requirements of Poultry. 9th Edition National Academy Press. Washington, D. C. Pp 1-114.

[20] Abdou Bouba A, Njintang YN, Foyet H, Scher J, Montet D and Mbofung C. (2012). Proximate composition, mineral and vitamin content of some wild plants used as spices in Cameroon. Food and Nutrition Sciences, 3 (4): 423-432. DOI: 10.4236/fns.2012.34061.

[21] Mcmullin P (2000). The future of anti-microbial growth promoter alternative for poultry production. In the new millennium. International Poultry Production, 8 (7): 1-30.

[22] Nuhu AM, Mshelis MS and Yakubu Y (2000). Antimicrobial screening of the bark extract of Pterocarpus erinaceus Tree. Journal of Chemical Society of Nigeria, 25: 85-86.

[23] Kambizi L. and Afolayan A. J. (2001). An ethnobotanical study of plants used for the treatment of sexually transmitted disease (njovhera) in Guruve District, Zimbabwe. Journal of Ethnopharmacology, 77(1): 5-9.

[24] Odeomelam V. U., Etuk I. F., Ndelekwute E. K., Iwuji T. C. and Ekwe C. C. (2013). Herbs and spices: Options for sustainable animal production. Journals of Biology, Agricultural and Healthcare, 3(7): 116-123.

[25] Ugwu S. O. C and A. E. Onyimonyi, (2008) Carcass, Organ and Organoleptic Charactteristics of Spent Layers Fed Bambara Nut Sievates. International Journal of Poultry Science. 7: 81-84.

[26] Barad N. A., Savsani H. H., Patil S. S., Gadaniya M. R., Murthy K. S. and Fefar D. T. (2017). Effect of supplementing the diet with coriander seeds, turmeric powder and black pepper on the feed intake, growth performance and carcass quality of broilers. The Indian Veterinary Journal, 94(1): 4345 .

[27] Kana J. R., Mube K. H., Ngouana T. R., Yangoue A., Kmguep R., Tsafong F. and Teguia A. (2017b). Growth performance and serum performance profile of broiler chickens fed on diets supplemented with Afrostyrax lepidophyllus fruit and bark as alternative to antibiotic growth promoters. Journal of Veterinary Medicine and Research, 4(6): 1-7.

[28] Simsek U. G., Ciftci M., Dalkilic B., Guler T. and Ertas O. N., 2007. The effects of dietary antibiotic and anise oil supplementation on body weight, carcass characteristics and organoleptic analysis of meat in broilers. Revue de Médecine Vétérinaire, 158: 514-518.

[29] Bawa, G. S., Orunmuyi, M., Agbaji, A. S. Ladan, Z. and Okekeifi, U. O. (2007). Effect of Different Methods of Processing Neem (Azadirachta indica), seeds on performance of young Rabbits. Pakistan Journal of Nutrition 6 (3): 212-216.

[30] Uchegbu, M. C. Okoli, T. C., Etuk, E. B, (2004). Preliminary Studies on Napoleona imperialis as livestock feed ingredient: proximate composition. Proceedings of the 36th Annual Conference of the Agricultural Society of Nigeria, FUT, Owerri, October 20 - 24, pp. $422-424$.

[31] Abdel Fattah SA, El-Sanhoury MH, El-Mednay NM and Abdel-Azem F. (2008). Tyroid activity, some blood constituents, organs morphology and performance of broiler chicks fed supplemental organic acids. International Journal of Poultry Science, 7 (3): 215- 222. 
[32] Kana JR, Teguia A, Mungfu BM and Tchoumboue J. (2011). Growth performance and carcass characteristics of broiler chickens fed diets supplemented with graded levels of charcoal from maize cob or seed of Canarium schweinfurthii Engl. Tropical Animal Health Production, 43: 51-56. DOI: 10.1007/s11250-010-9653-8.

[33] Toghyani M, Tohidi M, Gheisari AA and Tabeidian SA (2010). Performance, immunity, serum biochemical and hematological parameters in broiler chicks fed dietary thyme as alternative for an antibiotic growth promoter. African Journal of Biotechnology, 9: 6819- 6825. DOI: 10.5897/AJB09.1998.

[34] Fatemi, F., A. Allemah, A. Dadkhah, M. Forouzadeh, S. Kazemnejad and R. Sharifi ., 2006. Changes in hepatic cystolic glutathione S-transferase activity and expression of its Class-P during prenatal and postnatal periods in rat treated with aflatoxin B1. Arch Toxical 80: 572-579.

[35] Vahdatpour T., and Babazadeh., 2016. The effect of kefir rich in probiotic administration on serum enzymes and performance in male Japanese quails. The journal of animal and plant sciences, 26(1): 2016, Page: 34-39.

[36] Rehman S, Durrani FR, Chand N, Khan RU and Fawad UR (2011). Comparative efficacy of different schedules of administration of medicinal plants infusion on hematology and serum biochemistry of broiler chicks. Research Opinions in Animal and Veterinary Sciences, 1: 8-14.
[37] Ngouana Tadjong R, Kana JR, Tsafack Necdem B, Yemdjie Mane DD, Mube Kuietche H, Kuiede S, Teguia A and Meimandipour A (2017). Performances of Broiler Chickens Fed on Diet Supplemented with Thyme and Oregano Essential Oils Stabilized in a Plant Charcoal Matrix. J. World Poult. Res., 7 (2): 79-87.

[38] Bolukbasi S. C., Erhan M. K. and Ozkan A., 2006. Effect of dietary thyme oil and vitamin $\mathrm{E}$ on growth, lipid oxidation, meat fatty acid composition and serum lipoproteins of broilers. South Africa Journal of Animals Science, 36: 189196.

[39] Ahn, J., Grun, I. U., Mustapha, A., 2004. Antimicrobial and antioxidant activities of natural extracts in vitro and in ground beef. J. Food Protect., 67: 148-155.

[40] Luther, M., J. Parry, J. Moore, J. Meng, Y. Zhang, Z. Cheng, L. Yu, 2007: Inhibitory effect of Chardonnay and black raspberry seed extracts on lipid oxidation in fish oil and their radical scavenging and antimicrobial properties. Food Chem., 104: 1065-1073.

[41] Mohamed E. Abd El-Hack, Samir A. Mahgoub, Mahmoud Alagawany and Kuldeep Dhama, 2015. Influences of Dietary Supplementation of Antimicrobial Cold Pressed Oils Mixture on Growth Performance and Intestinal Microflora of Growing Japanese Quails. International Journal of Pharmacology, 11: 689-696. 